Research Article

\title{
Fetal Biometry Nomogram Based on Normal Population : an Observational Study
}

\author{
Nomogram Biometri Janin Berdasarkan Populasi Normal : \\ Suatu Penelitian Observasional
}

\author{
Aria Wibawa, Amanda Rumondang \\ Department of Obstetrics and Gynecology \\ Faculty of Medicine Universitas Indonesia/ \\ Dr. Cipto Mangunkusumo Hospital \\ Jakarta
}

\begin{abstract}
Objective: To establish fetal biometry nomogram using percentile method based on normal population.

Methods: A descriptive retrospective study in order to establish fetal biometry nomogram using percentile method based on normal population. Four fetal biometry measurement (BPD, HC, AC and FL) was collected from ultrasonography examination result in Fetomaternal Division Ultrasound Unit - Anggrek Clinic and from medical record unit Dr. Cipto Mangunkusumo General Hospital, from January 2015 until April 2016. Data being documented using case report form and being tabulated using Microsoft Excell 2011 Version 14.7.0 (161029). All data were analyzed using SPSS 20.0 dan Matlab R2016a.

Results: There were 6169 pregnant women underwent fetal biometry ultrasound within January 2015 - April 2016. Based on inclusion criteria, 2798 (45\%) were eligible as research sample distributed from 12 until 42 wga. Due to evenly distribution data, 2205 (78\%) were distributed from 20 until 40 wga to develop fetal biometry nomogram. Most pregnant women were 28.9 years old $(S D \pm 5.74)$ in range of $21-30(55 \%)$ years old. The youngest was 13 years old and the oldest was 45 years old. Four fetal biometry were collected and distributed evenly using percentile method to establish fetal biometry nomogram. As for estimated fetal weight curve was developed by Hadlock $C$ formula. Each biometry was calculated the $10^{\text {th }}$, $50^{\text {th }}$ and $90^{\text {th }}$ centile curves according to gestational age. Thus, representing the fetal biometry and modified Hadlock C estimated fetal weight nomogram based on normal population in Jakarta.
\end{abstract}

Conclusion: Each biometry and modified Hadlock $\mathrm{C}$ estimated fetal weight were calculated in $10^{\text {th }}, 50^{\text {th }}$ and $90^{\text {th }}$ centile curves according to gestational age represent fetal biometry nomogram based on normal population in Jakarta.

[Indones J Obstet Gynecol 2018; 6-3: 149-154]

Keywords: biometry, estimated fetal weight formula, nomogram

\begin{abstract}
Abstrak
Tujuan: Untuk mendapatkan nomogram biometri janin dengan pendekatan persentil berdasarkan populasi normal.

Metode: Penelitian ini merupakan penelitian deskriptif retrospektif untuk mendapatkan nomogram biometri janin dengan metode persentil pada populasi normal. Parameter biometri meliputi diameter biparietal (DBP), lingkar kepala (LK), lingkar perut (LP) dan panjang femur (PF). Data parameter biometri menggunakan data pemeriksaan USG di Divisi Fetomaternal-Klinik Anggrek dan data rekam medis RSUPN Dr. Cipto Mangunkusumo sepanjang Januari 2015 hingga April 2016. Data penelitian didokumentasikan pada formulir laporan kasus dan ditabulasi menggunakan software Microsoft Excell 2011 Version 14.7.0 (161029). Analisis data penelitian menggunakan SPSS 20.0 dan Matlab R2016a.
\end{abstract}

Hasil: Dari total 6169 data perempuan hamil yang melakukan pemeriksaan ultrasonografi biometri janin sejak Januari 2015 hingga April 2016, didapatkan 2798 (45\%) sampel data yang memenuhi kriteria inklusi penelitian. Data tersebut didistribusikan berdasarkan usia kehamilan dari usia kehamilan 12 minggu hingga 42 minggu. Normalitas sebaran data merupakan hal penting pada penelitian, sehingga dilakukan reduksi data agar mendapatkan sebaran normal untuk menghasilkan kurva dengan metode persentil. Hasil akhir didapatkan 2205 (78\%) sampel data penelitian yang didistribusikan dari usia kehamilan 20 minggu hingga 40 minggu untuk mendapatkan nomogram biometri janin dengan metode persentil. Data demografi menunjukkan rerata usia ibu hamil 28.9 tahun (SD \pm 5.74) dalam kelompok usia 21-30 tahun (55\%). Usia ibu hamil termuda 13 tahun dan yang tertua 45 tahun. Data empat parameter biometri dikumpulkan dan didistribusikan merata menggunakan metode persentil untuk menghasilkan nomogram biometri janin. Pada penelitian dihasilkan pula nomogram taksiran berat janin yang dikembangkan dari rumus Hadlock C. Data tiap parameter biometri janin dikalkulasikan berdasarkan persentil 10, 50 dan 90 sesuai usia kehamilan. Nomogram biometri janin dan taksiran berat janin modifikasi Hadlock Cyang dihasilkan merupakan gambaran nomogram berdasarkan populasi normal di Jakarta.

Kesimpulan: Gambaran nomogram tiap parameter biometri dan nomogram taksiran berat janin modifikasi Hadlock C persentil 10, 50 dan 90 sesuai usia kehamilan merupakan representasi nomogram biometri janin berdasarkan populasi normal di Jakarta.

[Maj Obstet Ginekol Indones 2018; 6-3: 149-154]

Kata kunci: biometri, formula taksiran berat janin, nomogram 


\section{INTRODUCTION}

Fetal growth is complex interaction between maternal-fetal-placental factors and has become fetal wellbeing indicators throughout pregnancy. ${ }^{1-3}$ Imbalance interaction between these factor will manifest into fetal growth disturbances, fetal growth restriction or macrosomia. Thus, high quality of ante natal care will detect normal or abnormal fetal growth. ${ }^{4-7}$

In order to improve maternal and neonatal health, including decrease perinatal death, high quality of ante natal care is a necessity. Not only by early detecting of high risk pregnancy, but also monitoring fetal growth. An accurate monitoring fetal growth will provide proper obstetric management. ${ }^{1,4-6}$ Therefore, it will prevent under/over treatment, decrease morbidity and prevent mortalilty. ${ }^{4-7}$

There are two methods known for monitoring fetal growth, clinical examination (fundal height measurement) and imaging method (fetal biometry ultrasonography).1,2,5,8 No significant differences in determining estimated fetal weight between clinical and imaging methods (64\% VS 62.5\%; $p$ > 0.2). ${ }^{1,9-12}$ Nevertheless, ultrasonography examination has become most obstetrician preferences due to its diagnostic values. ${ }^{1,8,12,13}$ Not only for monitoring fetal growth, but also evaluating fetal development and evaluating cause of fetal growth disturbances. ${ }^{2}$

Obstetricians use various fetal biometry parameters in monitoring fetal growth, standard and advanced measurement. Standard fetal biometry measurement are biparietal diameter (BPD), head circumference (HC), abdominal circumference (AC) and femur length (FL) ${ }^{1,2,8}$ Advanced fetal biometry measurement commonly use for special purposes, such as evaluating cause of fetal growth disturbances, evaluating fetal development and evaluating fetal nutritional status. ${ }^{1,2}$ Things to be concerned in monitoring fetal growth is fetal biometry parameters applied in estimating fetal weight formulas. It influences accuracy of estimated fetal weight result.8,11,14-16

There are two main concern in monitoring fetal growth, fetal biometry nomogram or curve and estimated fetal weight formulas being applied. Both are influencing examination result accuracy and in determining fetal growth disturbances. $3,6-8,15,17$ Accuracy in evaluating fetal growth will increase if fetal biometry nomogram apply is based on local population. $3,6,7$

There is no publication on fetal biometry nomogram based on our local normal population. This study was conducted to establish fetal biometry nomogram based on Indonesia normal population.

\section{METHODS}

This was a descriptive retrospective study in order to establish fetal biometry nomogram based on normal population using percentile method. It was conducted in Fetomaternal Division Ultrasonography Unit - Anggrek Clinic and Medical Record Unit Dr. Cipto Mangunkusumo General Hospital, during January - September 2016.

Standard fetal biometry parameters measurement, including biparietal diameter (BPD), head circumference $(\mathrm{HC})$, abdominal circumference (AC) and fetal length (FL) was collected from ultrasonography examination result in Fetomaternal Division Ultrasound Unit - Anggrek Clinic and from medical record unit Dr. Cipto Mangunkusumo General Hospital, from January 2015 until April 2016.

Inclusion criteria in this study, including : pregnant women underwent ultrasound fetal biometry examination in Fetomaternal Division Ultrasound Unit-Anggrek Clinic towards January 2015 - April 2016; criteria for determining last menstrual period : Last menstrual period from regular cycle, duration 25 - 35 days. Last 3 months menstrual cycle was regular, fetal biometry ultrasound examination in 10 - 12 wga, serial ultrasound examination in Fetomaternal Division Ultrasound Unit-Anggrek Clinic Dr. Cipto Mangunkusumo General Hospital; Last menstrual period was determined by 2 out of 3 criteria; Ultrasound examination was conducted between 12 wga until 42 wga; Singleton intrauterine live fetus; Pregnancy without complications.

We emphasize our study in normal population. Therefor, there were some exclusion criteria in this study, including : pregnancy with obesity; pregnancy with malnutrition; pregnancy with infection and chronic infection; pregnancy with mild and severe anemia; pregnancy with metabolic disorders; multiple pregnancy; intrauterine fetal death; fetal anomaly (lethal and non lethal); pregnancy with preeclampsia/eclampsia; pregnancy with autoimmune disease; smoking and alcohol consumption. 
All data being documented using case report form and being tabulated using Microsoft Excell 2011 Version 14.7.0 (161029). All data were analyzed using SPSS 20.0 and Matlab R2016a. This study was approved by Ethic Committee of Faculty of Medicine, Universitas Indonesia - Dr. Cipto Mangunkusumo General Hospital.

\section{RESULT}

Based on Fetomaternal Division-Anggrek Clinic documentation and medical record data, there were 6169 pregnant women underwent fetal biometry ultrasound examination from January 2015 until April 2016. There were 2798 samples met inclusion criteria varied from 12 wga until 42 wga.
Demographic characteristic was including patients age. Patients mean age underwent ultrasonography examination was 28.9 years old ( $\mathrm{SD} \pm 5.74$ ) in range $21-30$ years old (55\%). The youngest patient is 13 years old and the oldest 45 years old. Patients demographic characteristic was shown in Table. 1.

Table 1. Demographic Characteristics of Research Subject

\begin{tabular}{lc}
\hline Variable $(\mathbf{n}=\mathbf{2 2 0 5})$ & Description \\
\hline Age $(\text { Year })^{*}$ & $28.9 \pm 5.74$ \\
Age Distribution** & \\
$\leq 20$ & $156(7.1 \%)$ \\
$21-30$ & $1211(55 \%)$ \\
$31-40$ & $784(35.5 \%)$ \\
$41-50$ & $54(2.4 \%)$ \\
\hline \hline
\end{tabular}

${ }^{*}$ Numerical data evenly distributed were presented in mean $\pm S D$ ${ }^{*}$ Categorical data presented in $n(\%)$

Table 2. Fetal Biometry Parameters Characteristic

\begin{tabular}{|c|c|c|c|c|}
\hline Biometry Parameters & Gestational Age & $\mathbf{n}$ & Mean \pm SD & $95 \% \mathrm{CI}$ \\
\hline & 20 & 59 & $47.37 \pm 2.01$ & $46.83-47.90$ \\
\hline & 24 & 67 & $59.40 \pm 3.25$ & $58.60-60.19$ \\
\hline \multirow[t]{6}{*}{ Biparietal Diameter } & 28 & 111 & $71.36 \pm 4.24$ & $70.48-72.24$ \\
\hline & 32 & 146 & $80.63 \pm 4.90$ & $79.82-81.43$ \\
\hline & 36 & 150 & $88.96 \pm 8.03$ & $87.66-90.25$ \\
\hline & 40 & 127 & $93.40 \pm 3.60$ & $92.14-94.66$ \\
\hline & 20 & 59 & $173.35 \pm 8.19$ & $171.18-175.53$ \\
\hline & 24 & 67 & $219.06 \pm 15.12$ & $215.31-222.81$ \\
\hline \multirow[t]{7}{*}{ Head Circumference } & 28 & 111 & $258.76 \pm 13.53$ & $255.94-261.58$ \\
\hline & 32 & 146 & $288.25 \pm 12.50$ & $286.20-290.30$ \\
\hline & 36 & 150 & $315.62 \pm 16.12$ & $313.01-318.23$ \\
\hline & 40 & 127 & $325.35 \pm 13.92$ & $320.49-330.21$ \\
\hline & 20 & 59 & $154.02 \pm 9.43$ & $151.54-156.50$ \\
\hline & 24 & 67 & $196.50 \pm 10.819$ & $193.84-199.16$ \\
\hline & 28 & 111 & $239.06 \pm 13.504$ & $236.21-241.90$ \\
\hline \multirow[t]{6}{*}{ Abdominal Circumference } & 32 & 146 & $275.96 \pm 15.89$ & $273.35-278.57$ \\
\hline & 36 & 150 & $314.94 \pm 18.32$ & $311.97-317.91$ \\
\hline & 40 & 127 & $337.62 \pm 17.28$ & $331.59-343.65$ \\
\hline & 20 & 59 & $32.78 \pm 3.09$ & $31.97-33.59$ \\
\hline & 24 & 67 & $43.12 \pm 2.55$ & $42.49-43.75$ \\
\hline & 28 & 111 & $52.25 \pm 3.75$ & $51.46-53.04$ \\
\hline \multirow[t]{3}{*}{ Femur Length } & 32 & 146 & $59.98 \pm 3.77$ & $59.36-60.60$ \\
\hline & 36 & 150 & $68.59 \pm 3.41$ & $68.04-69.14$ \\
\hline & 40 & 127 & $73.05 \pm 2.08$ & $72.32-73.78$ \\
\hline
\end{tabular}

*Numerical data evenly distributed were presented in mean $\pm S D$ 
Main concern in this research is evenly distribution of data in order to establish nomogram with good precision. Therefor, we performed data reduction from total data met inclusion criteria. There were 2205 samples evenly distributed from 20 wga until 40 wga. Fetal biometry characteristic were shown in Table 2.

2205 data were then distributed using percentile method based on gestational age to establish fetal biometry nomogram based on normal popu- lation. Each fetal biometry parameters nomogram were compile in Figure 1.

In this study, we developed data to establish estimated fetal weight nomogram based on normal population in Jakarta. We used Hadlock C formula to establish estimated fetal weight nomogram based on normal population. Regression equation for each fetal biometry parameters were shown in Table 3.

\section{Fetal Biometry Nomogram Normal Population}

\section{Aria's Curve 2017}

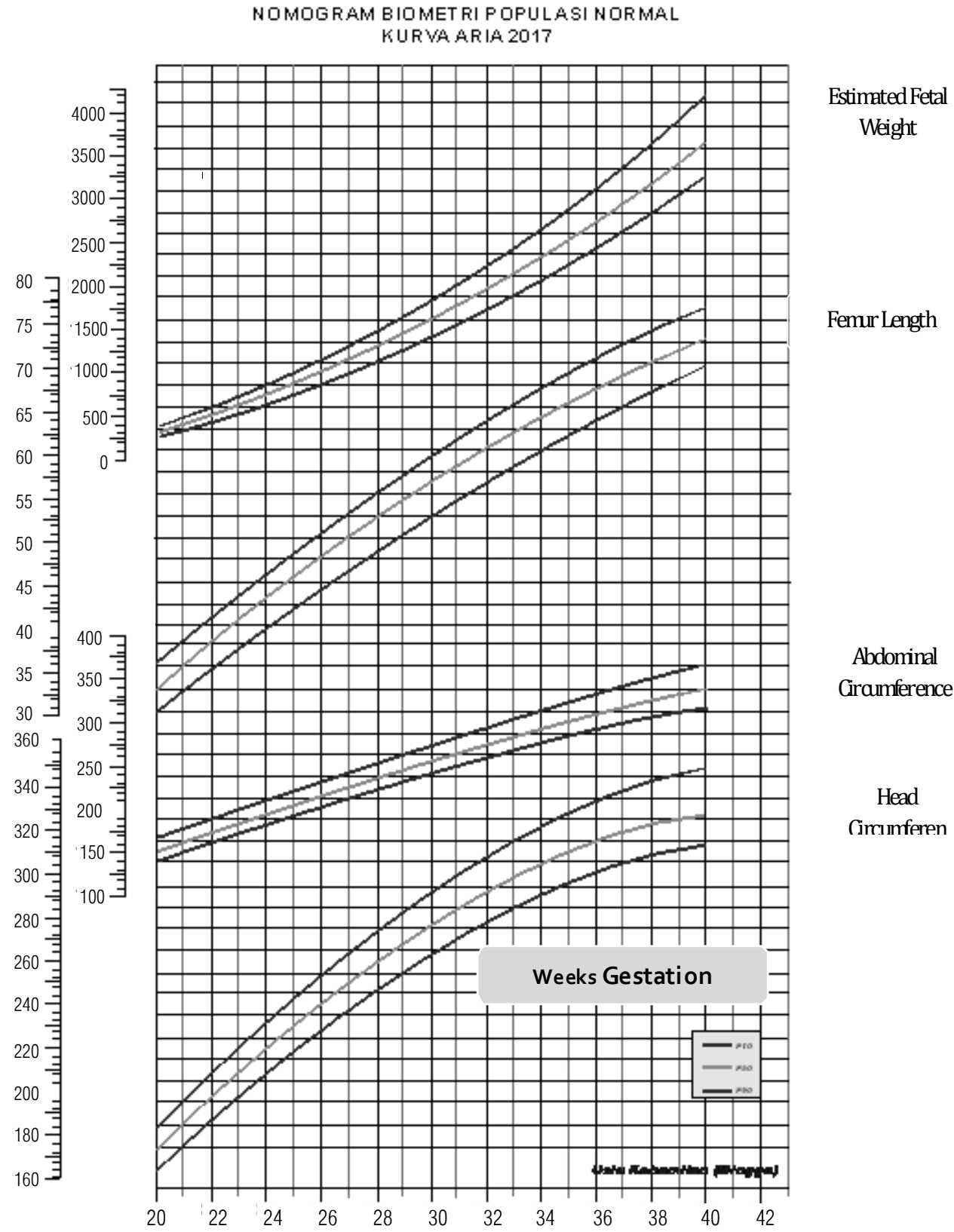

Figure 1. Fetal Biometry Nomogram Based on Normal Population 
Table 3. Fetal Biometry Nomogram Regression Equation Based on Percentile

\begin{tabular}{|c|c|c|}
\hline Biometry Parameters & Percentile & Regression Equation \\
\hline \multirow{3}{*}{ Biparietal Diameter } & P10 & $y=-0.059066 \times X^{2}+5.8359 \times X+(-49.309)$ \\
\hline & $\mathrm{P} 50$ & $y=-0.063745 \times X^{2}+6.1934 x X+(-51.889)$ \\
\hline & $\mathrm{P} 90$ & $y=-0.055744 \times X^{2}+5.7912 \times X+(-43.448)$ \\
\hline \multirow{3}{*}{ Head Circumference } & $\mathrm{P} 10$ & $y=-0.25332 \times X^{2}+22.604 x X+(-189.49)$ \\
\hline & $\mathrm{P} 50$ & $y=-0.26538 \times X^{2}+23.581 \times X+(-193.65)$ \\
\hline & $\mathrm{P} 90$ & $y=-0.25735 \times X^{2}+23.711 \times X+(-190.2)$ \\
\hline \multirow{3}{*}{ Abdominal Circumference } & P10 & $y=-0.25332 \times X^{2}+22.604 x X+(-189.49)$ \\
\hline & P50 & $y=-0.14188 \times X^{2}+17.888 \times X+(-150.21)$ \\
\hline & P90 & $y=-0.061531 \times X^{2}+13.583 x X+(-79.216)$ \\
\hline \multirow{3}{*}{ Femur Length } & $\mathrm{P} 10$ & $y=-0.028433 \times X^{2}+3.7173 \times X+(-32.72)$ \\
\hline & $\mathrm{P} 50$ & $y=-0.040289 x X^{2}+4.4826 x X+(-41.111)$ \\
\hline & P90 & $y=-0.03635 \times X^{2}+4.263 \times X+(-35.188)$ \\
\hline \multirow{3}{*}{ Estimated Fetal Weight } & P10 & $y=(-152.15)+(17.54 \times X)+\left(-0.14 \times X^{2}\right)$ \\
\hline & P50 & $y=(-150.21)+(17.89 \times X)+\left(-0.14 \times X^{2}\right)$ \\
\hline & $\mathrm{P} 90$ & $y=(-79.21)+(13.58 \times X)+\left(-0.06 \times X^{2}\right)$ \\
\hline
\end{tabular}

\section{DISCUSSION}

This is a descriptive retrospective study aimed to establish fetal biometry nomogram based on local normal population. By this means normal population in Jakarta. Selection of fetal biometry nomogram being applied influence evaluation accuracy in monitoring fetal growth. It is because race or ethnical characteristic between population are different. ${ }^{18}$ Therefor, we recommend using fetal biometry nomogram based on our local normal population. $5,18-20$

There is limited publication related fetal biometry research in Asia, specially Indonesia. No publication on fetal biometry nomogram based on Indonesia normal population. Thus, nomograms result from this study represent fetal biometry nomogram based on normal population in Jakarta.

This nomogram can be compared with other nomogram resulted form others population, such as Tokyo's Curve, Korean's Curve, Pakistan's Curve and also International population resulted from Intergrowth project. Based on our observational, mean difference between our curve compare to Tokyo's Curve and Intergrowth project was 1-2 mm for each biometry. As for Korean's Curve and Pakistan's Curve, our curve was smaller with mean difference 3-4 mm. Factor influence the result was total samples being used in the research, such as Intergrowth project that use 13.000 samples.
Method used in this research has advantages and disadvantages. Retrospective method used in this research had some benefits, specially time period conducting research. It needed short period time rather than longitudinal method to get data distribution evenly. Nevertheless, disadvantages using this method were non optimal controlling confounding factors. It influences result accuracy. In this research, confounding factor were controlled by research operational definition and only researcher conduct the selection and data collection.

As comparison, longitudinal or cross-sectional method has its own advantages. Confounding factor for longitudinal method can be controlled optimally, thus given advantages for the result. Meanwhile, it is needed longer period of time to conduct the research in order to get data distribution evenly. 5,18,20 Due to retrospective method used in this research, fetal biometry nomogram resulted need to be validated in order to be generalized in Indonesian population.

This research has some weakness, including : Retrospective data. This influence data accuracy due to non optimal confounding factors control; Less demographic characteristic data. Due to limitation of medical record data, such as height, body weight, haemoglobin and socio-economic; Validation data is needed in order to generalized data to be applied for Indonesian population. 


\section{CONCLUSION}

High quality of ante natal care is a necessity in order to improve maternal-neonatal health and decrease perinatal death. Thus, detection of high risk pregnancy during ante natal care, including fetal growth monitoring in detecting fetal growth disturbances. Each biometry and modified Hadlock C estimated fetal weight were distributed in $10^{\text {th }}$, $50^{\text {th }}$ and $90^{\text {th }}$ centile curves according to gestational age represent fetal biometry nomogram based on normal population in Jakarta.

\section{REFERENCES}

1. Bloemenkamp KWM. Fetal growth. International congress series. 2005: 295-301.

2. Lee W, Balasubramaniam M, Deter RL, Hassan SS, Gotsch F, Kusanovic JP, et al. Fetal growth parameters and birth weight: their relationship to neonatal body composition. Ultrasound Obstet Gynecol. 2009; 33(4): 441-6.

3. Mayer C, Joseph KS. Fetal growth: a review of terms, concepts and issues relevant to obstetrics. Ultrasound Obstet Gynecol. 2013; 41(2): 136-45.

4. Munim S, Morris T, Baber N, Ansari Y, Azam SI. Growth charts of fetal biometry: a longitudinal study. The journal of maternal-fetal \& neonatal medicine : the official J Eur Associat Perinatal Med, the Federation of Asia and Oceania Perinatal Societies, Int Soc Perinatal Obstet. 2012; 25(6): 692-8.

5. Papageorghiou AT, Ohuma EO, Altman DG, Todros T, Cheikh Ismail L, Lambert A, et al. International standards for fetal growth based on serial ultrasound measurements: the Fetal Growth Longitudinal Study of the Intergrowth-21st Project. Lancet. 2014; 384(9946): 869-79.

6. Verburg BO, Steegers EA, De Ridder M, Snijders RJ, Smith E, Hofman A, et al. New charts for ultrasound dating of pregnancy and assessment of fetal growth: longitudinal data from a population-based cohort study. Ultrasound Obstet Gynecol. 2008; 31(4): 388-96.

7. Zhang J, Merialdi M, Platt LD, Kramer MS. Defining normal and abnormal fetal growth: promises and challenges. Am J Obstet Gynecol. 2010; 202(6): 522-8.
8. Westerway S. Estimating fetal weight for best clinical outcome. AJUM. 2012; 1: 13-7.

9. Adam M, Tambul J, Yousef M, Sulieman A. The accuracy of ultrasound in estimation of fetal weight. J Am Scien. 2013; 9(12): 798-802.

10. Baum JD, Gussman D, Wirth JC, $3^{\text {rd }}$. Clinical and patient estimation of fetal weight vs. ultrasound estimation. J Reprod Med. 2002; 47(3): 194-8.

11. Njoku C, Emechebe C, Odusolu P, Abeshi S, Chukwu C, Ekabua J. Determination of Accuracy of Fetal Weight Using Ultrasound and Clinical Fetal Weight Estimations in Calabar South, South Nigeria. Int Sch Res Notices. 2014; 2014: 970-73.

12. RCOG. The investigation and management of the small-forgestational-age fetus. Green-top Guideline. 2014; 31: 1-34.

13. Ashrafganjooei T, Naderi T, Eshrati B, Babapoor N. Accuracy of ultrasound, clinical and maternal estimates of birth weight in term women. East Mediterr Health J. 2010; 16(3): 313-7.

14. Akinola R, Akinola O, Oyekan O. Sonography in fetal birth weigh testimation. Edu Research Review. 2009; 4(1): 16-20.

15. Burd I, Srinivas S, Pare E, Dharan V, Wang E. Is sonographic assessment of fetal weight influenced by formula selection? J Ultrasound Med. 2009; 28(8): 1019-24.

16. Kurmanavicius J, Burkhardt T, Wisser J, Huch R. Ultrasonographic fetal weight estimation: accuracy of formulas and accuracy of examiners by birth weight from 500 to $5000 \mathrm{~g}$. J Perinat Med. 2004; 32(2): 155-61.

17. Melamed N, Yogev Y, Meizner I, Mashiach R, Bardin R, BenHaroush A. Sonographic fetal weight estimation: which model should be used? J Ultrasound Med. 2009; 28(5): 61729.

18. Leung TN, Pang MW, Daljit SS, Leung TY, Poon CF, Wong $\mathrm{SM}$, et al. Fetal biometry in ethnic Chinese: biparietal diameter, head circumference, abdominal circumference and femur length. Ultrasound Obstet Gynecol. 2008; 31(3): 321-7.

19. Ray JG, Sgro M, Mamdani MM, Glazier RH, Bocking A, Hilliard R, et al. Birth weight curves tailored to maternal world region. J Obstet Gynecol Can. 2012; 34(2): 159-71.

20. Salomon LJ, Bernard JP, Duyme M, Buvat I, Ville Y. The impact of choice of reference charts and equations on the assessment of fetal biometry. Ultrasound Obstet Gynecol. 2005; 25(6): 559-65. 